College Art Association caa.reviews

October 30, 2007

Alexander Nehamas Only a Promise of Happiness: The Place of Beauty in a World of Art Princeton: Princeton University Press, 2007. 208 pp.; 8 color ills.; 79 b/w ills. Cloth \$29.95 (0691095213)

Peg Brand

CrossRef DOI: 10.3202/caa.reviews.2007.99

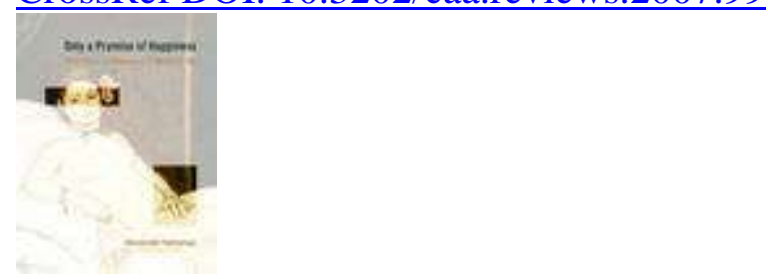

This is a grand work by a distinguished scholar in the field of aesthetics, and as such, deserves the attention of art historians, theorists, and artists in addition to the book's more predictable audience of philosophers. The scope of the phrase "world of art" is ambitious and extensive: Nehamas is as comfortable assessing ancient Greek art as he is rubbing elbows with the eighteenth-century man of taste, theorizing the gaze of Manet's Olympia, and judging John Currin's women to be beautiful bodies in ugly paintings.

Historical highlights are amply celebrated as Nehamas explores the place of beauty in art and, inevitably, the world at large. The standard opposition between passion and disinterest is cast as the choice between experiencing beauty as eros, love, and the desire to possess (for Plato and Plotinus) versus pure aesthetic judgment of taste (Kant), pleasure bereft of desire (Burke, Addison), and beauty as liberation (Schopenhauer). By the eighteenth century, disinterestedness and its attendant aesthetic pleasure became the philosophical ideal of art viewers, and this tradition has been continually augmented and modified by the ideas of Clive Bell, R. G. Collingwood, Arnold Isenberg, Monroe Beardsley, Alan Goldman, Guy Sircello, Mary Mothersill, and Arthur Danto. Philosophers launching the birth of modern aesthetics promoted conceptual distancing from a potentially undesirable, i.e., passionate and interested, reaction to beauty; this adopted stance served both to predispose and fuel artists' move away from beauty by the late nineteenth century. Modernist art criticism further undermined the role of beauty, famously separating it from aesthetic value, recognizable in the familiar words of Barnett Newman, "The impulse of modern art was to destroy beauty" (13; quoted in Nehamas). This history sets the stage for Nehamas to argue that in spite of the ancients' attempt to promote beauty as an avenue to truth, goodness, and ultimately happiness, beauty fails to deliver on its lofty goal. Instead, beauty offers only a promise of happiness; but this should be sufficient given that, "The value of beauty lies no further than itself; it is its own reward" (138). At the end of his book, Nehamas invokes the memory of Socrates, "And only the promise of happiness is happiness itself" (138).

Nehamas eloquently explores many familiar philosophical themes: reality versus appearance, the definition of "art" (e.g., in reference to work by Stelarc and Orlan), life experiences as the basis for judgments of taste, a cognitive - versus an emotion-based-approach to art, and the ever- 
present distinctions between artistic/aesthetic properties and non-artistic/non-aesthetic qualities of art. In a section entitled, "Beauty, Community, Universality," for instance, Nehamas undertakes a persistent question that "haunts modern aesthetics," viz., given our subjective responses to art, can there be universal judgments of beauty (79)? Here's where a thoughtful and detail-oriented analytic philosopher shines: a judgment is not (necessarily) the conclusion of an interpretation, or of true and false descriptions; rather, there are no sufficient conditions for beauty. To eliminate differences of opinion would result in a "nightmare" of uniformity where, "Universal aesthetic agreement would mark the end of aesthetics" (86).

In other discussions, however, Nehamas's thoroughness of thought seems lacking, as in his comparison of the power of art and beauty to that of friendship, which he argues by invoking Aristotle's concept of rare genuine friendship based on virtue. On Aristotle's view, women are disqualified from full rationality, virtue, and therefore friendship, so how fully can we appreciate a comparison that disenfranchises an entire sex? Along similar lines, Nehamas extends Ted Cohen's analogy between works of art and humor into the realm of beauty. Cohen contends that we enjoy humor and joke-telling because our shared reactions bond us together as members of a community - as insiders - who feel united; similar to shared responses to art, we belong to a particular group with special interests. But what about the exclusionary nature of a group that creates outsiders who fail to laugh at a joke because it makes fun of them or they find it offensive? Sigmund Freud cast obscene jokes as a way to shame women and thereby provide shared pleasure for men. Should our responses to beauty risk similar estrangement of a whole subgroup of persons who are not part of the privileged, insider group?

Nehamas, in fact, hints at the undercurrent of privilege, exclusivity, and elitism that runs throughout the entire philosophical history of beauty when he spotlights the eighteenth-century man of taste: "taste . . is something only some people possess to an appropriate degree" (49). For many theorists of the past several decades, however, this seriously understates the case. Invariably, the ideal judge of beauty, when made explicit, is a white male of privilege who has wealth, health, education, and opportunity. Nehamas rightly argues that each judgment of beauty is subjective, personal, and "central to our individual taste or sensibility, character or style" (85); but he fails to note that only certain persons qualify as men of taste whose judgments count. Within this philosophical framework, many judgments are summarily dismissed before they are even given the chance to be heard. It is important to remember that even in the eighteenth and nineteenth centuries the legacy of Aristotle held sway; Enlightenment philosophers did not deem women fully rational, capable of virtue, or possessors of taste. They were (literally) objects of beauty (in art as in real life); they were denied a voice and could not express judgments of taste. Recall the deadly pall cast upon beauty when the Christian fathers exerted their opinion of women as descendents of Eve, later influencing philosophers like Schopenhauer: "Beauty itself was often taken to be the seductive face of evil, a delightful appearance masking the horrid skull beneath the skin" (10; quoted in Nehamas). Feminist scholarship since the 1970s, for example, presents a thorough critique of canonical depictions of white female bodies by Praxiteles, Titian, Balthus, Bouguereau, Boucher, Ingres, Cabanel, Matisse, Picasso, and Manet (all examples used by Nehamas). But this scholarship plays no serious role here, particularly in the discussion of the revered depiction of Olympia. As with other laudatory accounts, it is primarily men of taste from the past two centuries who enjoy Victorine Meurend's outward stare. 
In attempting to explain this shared fascination with "Olympia's elusive gaze" (128), Nehamas takes Jean Clay's 1983 theory (“Ointment, Makeup, Pollen," October 27 (1983): 3-44) one step further, arguing that Manet painted Olympia herself being photographed. This is why the painting fails to make narrative sense as a painting: i.e., the beholder becomes the photographer; he shifts to the client's role; and "Olympia's look, aware and indifferent, acknowledges her clients as it casts them aside" (120). The typical male gazer is gratified (i.e., titillated) and challenged. The painting has "a double being - both inanimate matter and alluring creature," and as such is a paradigm of Manet's multi-layered modernism (120). One is tempted to contrast other readings of Olympia that further complicate the spatial dynamic on view, e.g., a recent interpretation by Charles Harrison in Painting the Difference: Sex and Spectator in Modern Art. (Chicago: University of Chicago Press, 2005), where he posits a "psychological transaction between a solitary spectator and a representational image" (153), or Eunice Lipton's Alias Olympia: A Woman's Search for Manet's Notorious Model and Her Own Desire (New York: Meridian, 1994), which more fully probes the personality of the sitter, showing sensitivity to her plight as a struggling artist and acknowledging that she is more than just "a prostitute" on display. One might also be tempted to compare what Nehamas describes as the "frank stare" and "unabashed gaze" (115) of Victorine to that of Cindy Sherman or Renée Cox.

The ideas presented in Only a Promise of Happiness: The Place of Beauty in a World of Art were originally delivered as the Townsend Lectures in 2000 at the University of California at Berkeley and the Tanner Lectures on Human Values at Yale University in 2001, and Nehamas's goal- to reinvigorate the dialogue on the role of beauty in our lives - is surely worthy. But a renewed passion for beauty should also include an examination of the questions, "Whose beauty?" and "Beauty for whom?"

If "beauty is part of the everyday world" (35) and its aesthetic features necessitate being directly experienced (even if they are not perceptual, and beauty is not necessarily a matter of appearance), and if, furthermore, beauty promises happiness "that is impossible to find anywhere else" (101), then it is appropriate to cast a wide net and to offer "irreplaceable" (99) beautiful objects that provide opportunities and promise to all, not just a select few. While doing so, perhaps beauty - as the object of love — can acknowledge the power of passion and desire without necessarily becoming possessive. If beauty is forward-looking, then let's open the playing field to all. Whether beauty offers only the promise of happiness or the ultimate goal of happiness itself, the pursuit should be democratic and fair.

\section{Peg Brand}

Associate Professor, Department of Philosophy, Women's Studies Program, Indiana University Purdue University-Indianapolis 